\title{
SEBARAN POPULASI, PERSENTASE SERANGAN, DAN TINGKAT KERUSAKAN AKIBAT HAMA BOKTOR PADA TANAMAN SENGON: PENGARUH UMUR, DIAMETER, DAN TINGGI POHON
}

\author{
Population Distribution, Damage Percentage, and Damage Level due to Boktor in Sengon: \\ Effect of Age, Diameter, and Tree Height
}

\author{
Asep Hendra Supriatna ${ }^{1}$, Noor Farikhah Haneda ${ }^{1}$, dan Imam Wahyudi ${ }^{2}$ \\ ${ }^{1}$ Departemen Silvikultur, Fakultas Kehutanan IPB \\ ${ }^{2}$ Departemen Hasil Hutan, Fakultas Kehutanan IPB
}

\begin{abstract}
One of the most important pest that attacks sengon stands is boktor (Xystrocera festiva). Boktor attacks tree stem and causing high damage in term of biological, physiological and economical side. The aim of this study was to analyze damage percentage and damage level on sengon stand in terms of age, diameter and height. The result shows that boktor is starting to attack when the sengon stands are 3 years old with damage percentage and damage level were $20.26 \%$ and $13.32 \%$, respectively. It increased along with the increasing of age, diameter, and height. The highest percentage of damage and level of damage found in 5 years old of sengon stand i.e. $53.71 \%$ and $38.07 \%$, respectively. The enhancement of percentage and level of damage caused by the abundant source of food, insect behavior and pest management. Boktor mostly attacks sengon stands in the range of $15.5-18.5 \mathrm{~cm}$ in diameter (frequency $=30$ trees/ha) and 18.5-21.5 $\mathrm{m}$ (frequency $=40$ trees $/$ ha) in total height .
\end{abstract}

Key words: boktor, damage percentage, damage level, sengon, tree age

\section{PENDAHULUAN}

Sengon (Falcataria moluccana (Miq.) Barneby \& J.W. Grimes) merupakan salah satu jenis tanaman yang banyak ditanam pada hutan tanaman industri maupun hutan rakyat di Indonesia khususnya di Pulau Jawa. Selain produktivitasnya tinggi, cepat tumbuh, dan mudah beradaptasi pada berbagai jenis tanah, kayu yang dihasilkan multifungsi, baik sebagai bahan baku industri pulp dan kertas, konstruksi ringan, papan serat, papan partikel, vinir, korek api maupun kayu bakar.

Di KPH Kediri, Perum Perhutani Unit II Jawa Timur, sengon ditanam dalam pola monokultur dengan kemlandingan atau petai cina (Leucaena leucocephala) sebagai tanaman sela, mindi (Melia azedarach) sebagai tanaman tepi, dan secang (Caesalpinia sapan) sebagai tanaman pagar. Meskipun demikian, permasalahan hama dan penyakit tanaman masih terjadi. Salah satu contohnya adalah serangan hama penggerek batang Xystrocera festiva Thombs. (Coleoptera: Cerambycidae) atau sering disebut sebagai boktor atau uter-uter. Sampai saat ini, boktor dianggap sebagai hama yang paling merugikan pada hutan sengon karena menyebabkan kematian, patahnya batang dan menurunkan jumlah dan kualitas kayu yang dihasilkan (Husaeni 2010).

Berdasarkan tahapan perkembangan hidupnya, larva boktor merupakan fase yang paling merusak karena mampu menyerang kambium dan bagian luar dari kayu gubal, dan meninggalkan bekas berupa lubang gerek.
Lubang gerek pada pohon sengon akan menyebabkan batang pohon menjadi rusak atau cacat (nilai jualnya turun), mengering, dan rentan tumbang oleh tiupan angin. Besarnya kerusakan yang ditimbulkan oleh larva dipengaruhi oleh jumlah larva dan banyaknya lubang gerek yang ada dalam setiap batang pohon atau per satuan hektar (ha). Oleh karena itu, pengukuran jumlah larva dan jumlah lubang gerek, persentase serangan, dan juga tingkat serangan perlu dilakukan untuk mendapatkan data dan informasi mengenai seberapa besar tingkat kerusakan dan kerugian secara ekonomis akibat dari serangan boktor. Selain itu, informasi tersebut dapat memberikan gambaran mengenai pada umur tegakan berapa tahun, sengon mulai terserang dan kisaran diameter dan tinggi pohon berapa yang paling banyak terserang?

Berdasarkan uraian di atas, dan mengingat penelitian sejenis masih terbatas, maka tujuan penelitian ini adalah untuk menganalisis persentase serangan dan tingkat kerusakan pada tegakan sengon dari segi umur, diameter, dan tinggi pohon akibat hama boktor.

\section{METODE}

\section{Waktu dan Tempat Penelitian}

Penelitian dilaksanakan di Resort Pemangkuan Hutan (RPH) Pandantoyo, Bagian Kesatuan Pemangkuan Hutan (BKPH) Pare, Kesatuan 
Pemangkuan Hutan (KPH) Kediri, Perum Perhutani Unit II Jawa Timur. Pengambilan data dilaksanakan pada bulan Januari 2016.

\section{Alat dan Bahan}

Alat yang digunakan adalah GPS, pita ukur (meteran), haga hypsometer, tangga, tally sheet, alat tulis, kamera, kaliper, golok, hygro-thermometer, spidol permanen, label, dan komputer. Bahan utama yang digunakan adalah tegakan sengon berumur 1 hingga 5 tahun.

\section{Metode Penelitian}

Data yang diamati adalah diameter pohon setinggi dada (1.3 $\mathrm{m}$ dari permukaan tanah), tinggi bebas cabang, tinggi total pohon, jumlah larva boktor per pohon, jumlah lubang gerek per pohon, dan jumlah pohon sengon yang terserang. Data diperoleh melalui pengukuran dan pengamatan di lapangan. Pada setiap umur tegakan dibuat 2 buah plot contoh berbentuk lingkaran dengan luas 0.1 ha (jari-jari $17.8 \mathrm{~m}$ ) yang diletakkan secara acak. Pada setiap plot contoh dilakukan kegiatan sebagai berikut: 1) Mengukur diameter, tinggi bebas cabang dan tinggi total pohon, 2) Mencatat jumlah pohon sengon yang terserang hama boktor, 3) Menghitung jumlah lubang gerek dan jumlah larva pada semua tanaman sengon yang terserang di dalam plot. Perhitungan jumlah larva dilakukan dengan cara menyeset kulit batang pohon sehingga larva dan lubang gerek dapat dilihat, dan 4) Mencatat suhu dan kelembaban relatif udara di setiap plot contoh dengan menggunakan hygro-thermometer.

\section{Analisis Data}

Analisis data yang digunakan adalah metode deskriptif. Data pohon yang terserang dikelompokkan ke dalam kelas diameter dan tinggi total pohon yang sama. Persentase serangan diperoleh berdasarkan perbandingan antara jumlah pohon yang terserang terhadap jumlah total pohon yang ada di dalam satu plot pengamatan. Rumus yang digunakan adalah (Herdiana 2010):

Keterangan:

$$
P S(\%)=\frac{N h}{N t} \times 100
$$

PS $=$ Persentase serangan $(\%)$

$\mathrm{Nh}=$ Jumlah pohon yang terserang dalam plot pengamatan

$\mathrm{Nt}=$ Jumlah total pohon yang ada di dalam plot pengamatan.

Tingkat kerusakan serangan boktor diperoleh berdasarkan klasifikasi dari parameter yang diukur pada individu pohon yang terserang dan akibatnya pada pohon itu sendiri. Menurut Husaeni (2010), tingkat kerusakan serangan hama boktor ditentukan oleh banyaknya larva atau banyaknya lubang gerek dalam satu pohon sengon. Parameter dan tingkat kerusakan dapat dilihat pada Tabel 1 dan 2 .
Tabel 1 Parameter kerusakan yang diamati

\begin{tabular}{|c|c|c|}
\hline No. & Parameter Kerusakan & Nilai Kerusakan \\
\hline \multirow[t]{9}{*}{1} & Tinggi lubang gerek (m) & \\
\hline & $1.5-3.5$ & 8 \\
\hline & $3.5-5.5$ & 7 \\
\hline & $5.5-7.5$ & 6 \\
\hline & $7.5-9.5$ & 5 \\
\hline & $9.5-11.5$ & 4 \\
\hline & $11.5-13.5$ & 3 \\
\hline & $13.5-15.5$ & 2 \\
\hline & $>15.5$ & 1 \\
\hline \multirow[t]{9}{*}{2} & $\begin{array}{l}\text { Jumlah larva boktor yang } \\
\text { ditemukan (ekor) }\end{array}$ & \\
\hline & $0-5$ & 1 \\
\hline & $6-10$ & 2 \\
\hline & $11-15$ & 3 \\
\hline & $16-20$ & 4 \\
\hline & $21-25$ & 5 \\
\hline & $26-30$ & 6 \\
\hline & $31-35$ & 7 \\
\hline & $>35$ & 8 \\
\hline \multirow[t]{9}{*}{3} & $\begin{array}{l}\text { Banyaknya lubang gerek } \\
\text { (lubang) }\end{array}$ & \\
\hline & $0-5$ & 1 \\
\hline & $6-10$ & 2 \\
\hline & $11-15$ & 3 \\
\hline & $16-20$ & 4 \\
\hline & $21-25$ & 5 \\
\hline & $26-30$ & 6 \\
\hline & $31-35$ & 7 \\
\hline & $>35$ & 8 \\
\hline
\end{tabular}

Sumber: Husaeni 2010

Tingkat kerusakan serangan hama boktor dihitung berdasarkan rumus (Herdiana 2010):

$$
T K(\%)=\frac{\sum(n \times k)}{Z \times N} \times 100
$$

Keterangan:

$\mathrm{TK}=$ Tingkat kerusakan $(\%)$

$\mathrm{k}=$ Nilai kerusakan tiap parameter

$\mathrm{n} \quad=$ Jumlah pohon terserang yang memiliki nilai kerusakan yang sama pada parameter yang sama

$\mathrm{Z}=$ Nilai tertinggi dari jumlah nilai kerusakan $(8 \mathrm{x}$ 3 parameter)

$\mathrm{N}=$ Jumlah pohon yang ada di dalam plot pengamatan.

Tabel 2 Klasifikasi tingkat kerusakan serangan hama boktor

\begin{tabular}{ccc}
\hline No. & Tingkat Kerusakan $(\%)$ & Kategori \\
\hline 1 & 0 & Sehat \\
2 & $1-20$ & Ringan \\
3 & $21-40$ & Sedang \\
4 & $41-60$ & Agak Berat \\
5 & $61-80$ & Berat \\
6 & $>80$ & Sangat Berat \\
\hline
\end{tabular}

Sumber: Herdiana 2010

\section{HASIL DAN PEMBAHASAN}

Rekapitulasi persentase serangan, tingkat kerusakan, dan kategori tingkat kerusakan akibat hama bokor pada 
tegakan sengon umur 1 hingga 5 tahun di areal penelitian disajikan pada Tabel 3 .

Berdasarkan Tabel 3 diketahui bahwa serangan boktor dimulai pada umur tegakan 3 tahun dengan persentase serangan $20.26 \%$ dan dikategorikan sebagai kerusakan ringan (13.32\%). Hasil tersebut sesuai dengan yang ditemukan oleh Puspitarini (2006) dalam Husaeni 2010, dan Prisanda (2006) dalam Husaeni 2010. Pada tabel tersebut juga dapat dilihat bahwa terdapat peningkatan kategori tingkat kerusakan mulai dari sehat (umur tegakan 1 tahun) hingga sedang (umur tegakan 5 tahun). Peningkatan kategori ini berbanding lurus dengan penambahan diameter dan tinggi pohon.

Nilai persentase serangan pada umur tegakan 5 tahun tergolong besar dan dinilai merugikan bagi pengusahaan hutan sengon. Lebih dari 50\% sengon yang ditanam terserang oleh boktor. Meskipun kategorinya tergolong sedang namun bagi pengusahaan hutan, banyaknya pohon yang terserang menyebabkan penurunan hasil produksi khususnya untuk kayu pertukangan.

Hasil pengamatan memperlihatkan bahwa pada pohon yang terserang boktor banyak dijumpai lubang gerek hingga kedalaman $20 \mathrm{~cm}$. Menurut Ichtisinii (2011), larva memakan hemiselulosa dan selulosa sehingga menimbulkan kerusakan pada batang berupa lubang gerek. Hal tersebut membuat kayu yang dihasilkan oleh pohon yang telah terserang tidak layak digolongkan sebagai bahan baku kayu pertukangan (reject) karena berdasarkan SNI, kayu bulat untuk kelas mutu pertama tidak diperbolehkan memiliki lubang uter-uter (boktor). Kayu bulat yang memiliki lubang gerek langsung masuk ke dalam kelas mutu dua (SNI 2001). Pada kasus di Perhutani, kayu bulat sengon yang memiliki cacat boktor bahkan langsung digolongkan ke dalam kayu bakar (rencek) sehingga menurunkan produksi kayu bulat rimba dan menimbulkan kerugian secara ekonomi.

\section{Populasi Boktor, Persentase Serangan dan Tingkat Kerusakan terhadap Umur Tanaman}

Gambar 1 menunjukkan bahwa serangan boktor terjadi pada tegakan umur 3 tahun dengan persentase serangan dan tingkat serangan masing-masing sebesar $20.26 \%$ dan $13.32 \%$. Serangan boktor belum terjadi pada tegakan yang berumur 1 dan 2 tahun. Pada tegakan umur 4 tahun persentase serangan meningkat sebesar $7.72 \%$, sedangkan tingkat serangan meningkat sebesar $5.29 \%$. Pada tegakan umur 5 tahun persentase serangan dan tingkat serangan merupakan nilai tertinggi, masingmasing sebesar $53.71 \%$ dan $38.07 \%$.

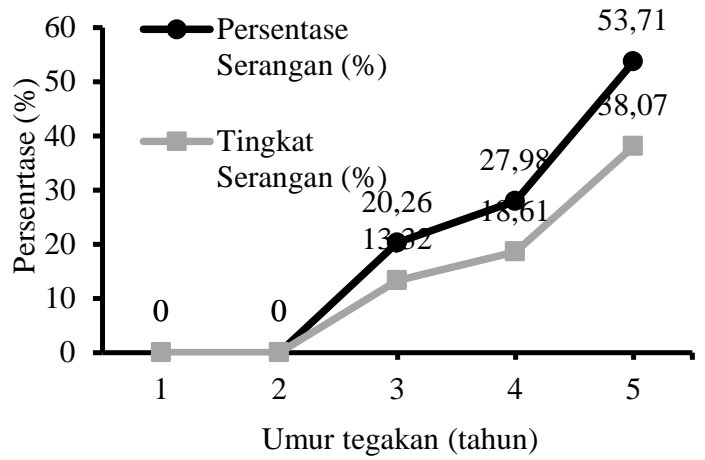

Gambar 1 Persentase serangan dan tingkat serangan boktor berdasarkan umur tanaman.

Gambar 1 menunjukkan bahwa setiap bertambahnya umur tegakan, persentase dan tingkat serangan boktor akan semakin meningkat. Selain dipengaruhi oleh perilaku boktor itu sendiri, peningkatan persentase dan tingkat serangan juga dipengaruhi oleh dimensi pohon dan faktor perlakuan pengendalian yang diterapkan. Menurut Husaeni (2010), larva memiliki masa hidup yang sangat panjang, yaitu selama 118 hari. Panjangnya masa hidup larva mengakibatkan semakin tinggi kerusakan yang terjadi pada pohon karena semakin banyak bagian batang yang diserang (dimakan). Selain itu, larva tersembunyi di balik kulit batang sehingga relatif aman dari serangan pemangsa, parasitoid dan juga perubahan lingkungan. Akibatnya persentase dan tingkat serangan boktor juga semakin tinggi. Dengan bertambahnya umur tegakan, dimensi pohon juga bertambah. Larva mampu hidup lama di dalam batang dikarenakan sumber makanannya yang berlimpah (dimensi pohon bertambah) dan kondisinya sesuai (Gambar 2a). Meskipun demikian, dijumpai juga ada beberapa larva yang mati karena jamur (Gambar 2b). Salah satu jenis jamur patogen yang dapat mematikan boktor adalah Beauveria bassiana (Husaeni 2010).

Tabel 3 Rekapitulasi rata-rata hasil pengukuran

\begin{tabular}{|c|c|c|c|c|c|c|}
\hline $\begin{array}{l}\text { Umur } \\
\text { Tegakan } \\
\text { (tahun) }\end{array}$ & Diameter $(\mathrm{cm})$ & $\begin{array}{l}\text { Tinggi Bebas } \\
\text { Cabang (m) }\end{array}$ & Tinggi Total (m) & $\begin{array}{c}\text { Persentase } \\
\text { Serangan }(\%)\end{array}$ & $\begin{array}{c}\text { Tingkat } \\
\text { Kerusakan } \\
(\%)\end{array}$ & $\begin{array}{c}\text { Kategori } \\
\text { Tingkat } \\
\text { Kerusakan }\end{array}$ \\
\hline 1 & $3.52 \pm 1.06$ & $1.84 \pm 0.57$ & $2.99 \pm 0.69$ & 0 & 0 & Sehat \\
\hline 2 & $10.03 \pm 2.15$ & $4.01 \pm 1.14$ & $6.54 \pm 1.52$ & 0 & 0 & Sehat \\
\hline 3 & $16.13 \pm 4.46$ & $6.91 \pm 2.42$ & $12.21 \pm 3.07$ & 20.26 & 13.32 & Ringan \\
\hline 4 & $19.34 \pm 5.85$ & $6.50 \pm 2.71$ & $16.66 \pm 4.11$ & 27.98 & 18.61 & Ringan \\
\hline 5 & $23.35 \pm 5.67$ & $8.26 \pm 3.98$ & $16.99 \pm 5.45$ & 53.71 & 38.07 & Sedang \\
\hline
\end{tabular}




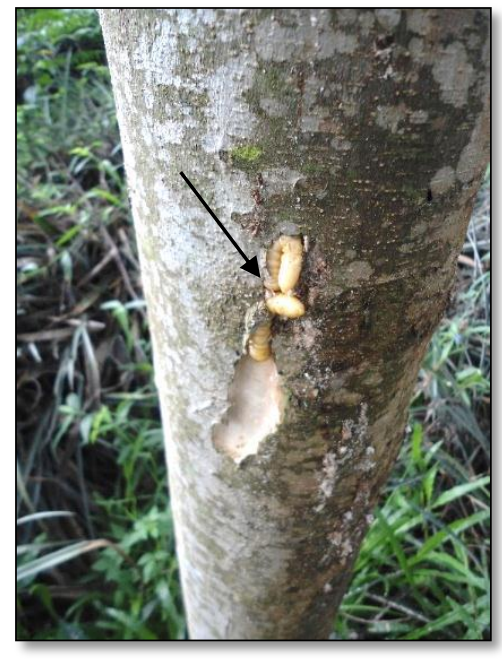

(a)

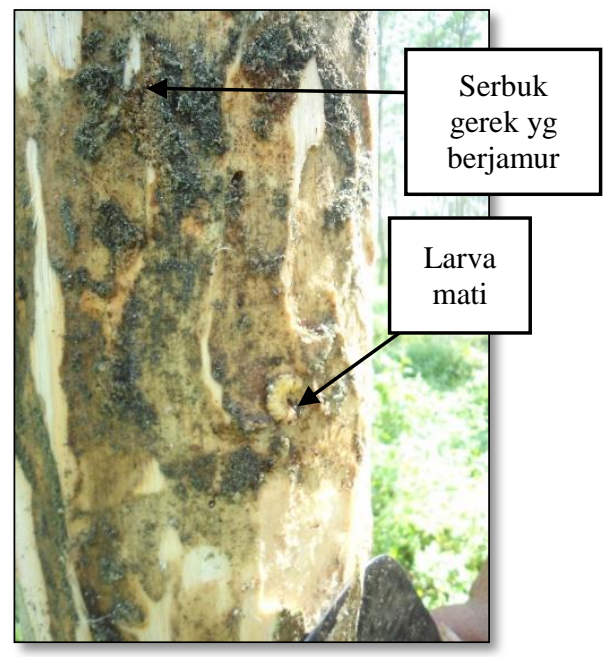

(b)

Gambar 2 Kondisi pohon sengon yang terserang boktor: (a) Larva yang tersembunyi di balik kulit kayu; (b) Kondisi larva yang mati akibat lembab dan jamur.

Faktor pengendalian yang mempengaruhi serangan boktor di lokasi penelitian adalah adanya perlakuan penjarangan yang dilakukan, yang ternyata tidak berhasil menurunkan serangan boktor. Satu tahun setelah dijarangi, jumlah larva boktor pada tahun berikutnya meningkat (Gambar 3a), begitu pula jumlah lubang gerek maupun jumlah larva per pohon (Gambar $3 b)$. Penjarangan dimulai pada umur 3 tahun, dan dilakukan setiap tahun hingga tegakan siap tebang (6 tahun). Penjarangan yang dimaksudkan untuk mengurangi populasi tegakan sekaligus mengurangi kompetisi unsur hara dan cahaya matahari, dilakukan dengan cara menebang beberapa pohon yang cacat, terkena serangan hama dan penyakit, ataupun pertumbuhannya lambat (kerdil).

Tidak efektifnya kegiatan penjarangan disebabkan karena pohon yang ditebang berupa pohon-pohon yang terserang, sedangkan beberapa pohon yang meskipun sudah terinfeksi larva namun terlihat masih sehat malah dibiarkan (tidak ditebang) (Matsumoto 1994).

Gambar 3 menunjukkan bahwa terdapat hubungan yang berbanding lurus antara jumlah larva dan jumlah lubang gerak terhadap peningkatan umur tegakan, baik per ha maupun per batang pohon. Pada Gambar 3a terdapat peningkatan jumlah larva dan lubang gerek yang tajam pada umur tegakan 4 menuju 5 tahun, sedangkan pada Gambar 3b jumlah larva dan lubang gerek mengalami peningkatan yang tajam pada umur tegakan 2 menuju 3 tahun, setelah itu peningkatan tidak terlalu tajam.

Pada umur 4 tahun terlihat peningkatan jumlah lubang gerek dan jumlah larva yang kurang signifikan (Gambar 3). Hal tersebut dikarenakan adanya kegiatan penjarangan pertama sehingga pohon yang terserang akan ditebang dan penyebaran boktor dapat diperlambat. Akan tetapi, tegakan sengon umur 4 tahun merupakan periode yang sesuai untuk perkembangbiakan kumbang Xystrocera festiva (Prisanda 2006 dalam Husaeni 2010) sehingga terlihat pada Gambar 3 populasi boktor meningkat tajam. Peningkatan populasi boktor pada tegakan sengon 5 tahun dapat disebabkan oleh kondisi tegakan yang kondusif, yaitu tegakan yang rapat, tajuk rindang, diameter yang semakin besar, dan penyebaran boktor yang sudah merata dan meningkat.
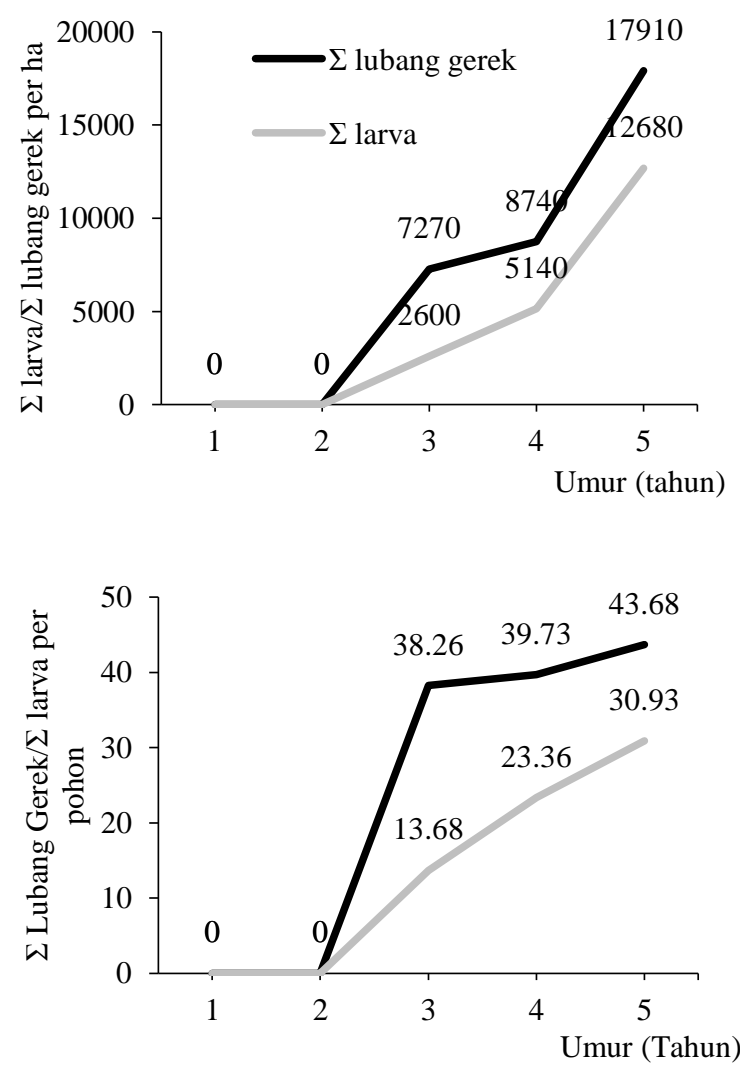

Gambar 3 Jumlah lubang gerek dan larva boktor terhadap umur tegakan sengon: (a) jumlah lubang gerek dan larva boktor per ha, (b) rata-rata lubang gerek dan larva per pohon sengon yang terserang.

Pada Gambar 3 terlihat bahwa bekas lubang gerek pada pohon yang terserang jumlahnya lebih banyak dibandingkan dengan jumlah larva yang ditemukan, 
baik per ha maupun rata-rata per pohon. Hal tersebut disebabkan oleh kecilnya kesempatan larva untuk berkembang hingga tahap pupa dan dewasa (Tarumingkeng 1994). Adanya keterbatasan daya dukung lingkungan (ketersediaan makanan maupun persaingan didalam memperebutkan sumber makanan), predator, dan penyakit mengakibatkan rendahnya tingkat probabilitas untuk mencapai tahapan pupa dan dewasa.

Rendahnya jumlah larva (baik per ha maupun per pohon) bertolak belakang dengan perilaku boktor yang mampu menyimpan 220 - 457 telur per pohon (Franssen 1931; Wongtong 1974; Notoatmodjo 1963 dalam Husaeni 2010), serta kemampuan imago dewasa menyerang pohon yang sama berulang kali (Flowrensia et al. 2015).

\section{Sebaran Populasi Boktor terhadap Diameter Sengon}

Serangan boktor mulai ditemukan pada diameter $10.51 \mathrm{~cm}$ hingga $33.44 \mathrm{~cm}$ (Gambar 4). Boktor paling banyak menyerang pohon pada kisaran diameter 15.5$18.5 \mathrm{~cm}$ (frekuensi = 30 pohon per ha). Berdasarkan hasil analisis, ditemukan bahwa pada umur 3 tahun, serangan paling parah terjadi pada diameter $19.11 \mathrm{~cm}$, sedangkan pada umur tegakan 4 tahun terjadi pada diameter $32.80 \mathrm{~cm}$. Pada tegakan umur 5 tahun, serangan paling parah terjadi pada kisaran diameter $25.80-31.85 \mathrm{~cm}$

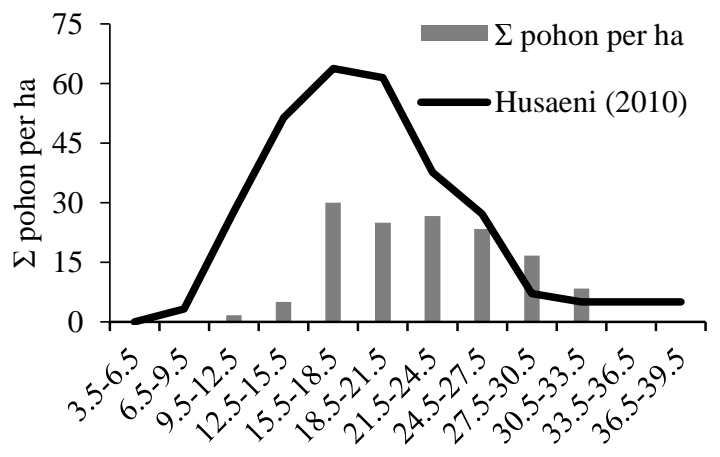

Kelas Diameter $(\mathrm{cm})$

Gambar 4 Sebaran pohon sengon yang terserang berdasarkan kelas diameter batang.

Gambar 5 menyajikan grafik hubungan antara jumlah larva dan jumlah lubang gerek terhadap diameter pohon yang terserang dengan model linier sederhana. Baik jumlah larva dengan diameter mau pun jumlah lubang gerek dengan diameter pada setiap umur tegakan (3, 4 dan 5 tahun) memperlihatkan hubungan yang berbeda.

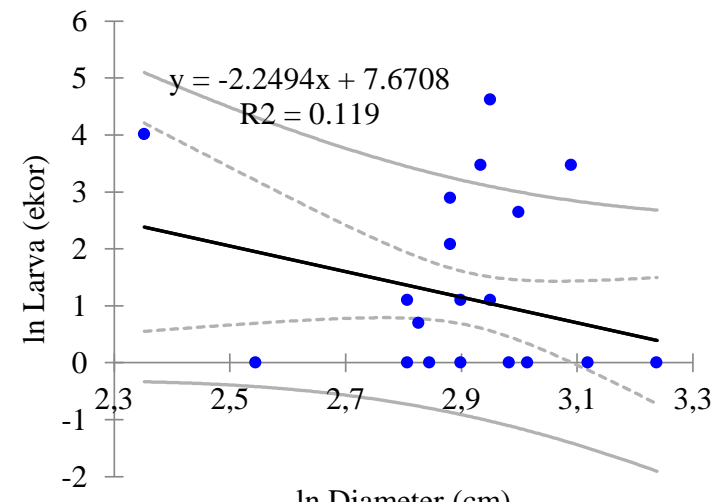

ln Diameter $(\mathrm{cm})$

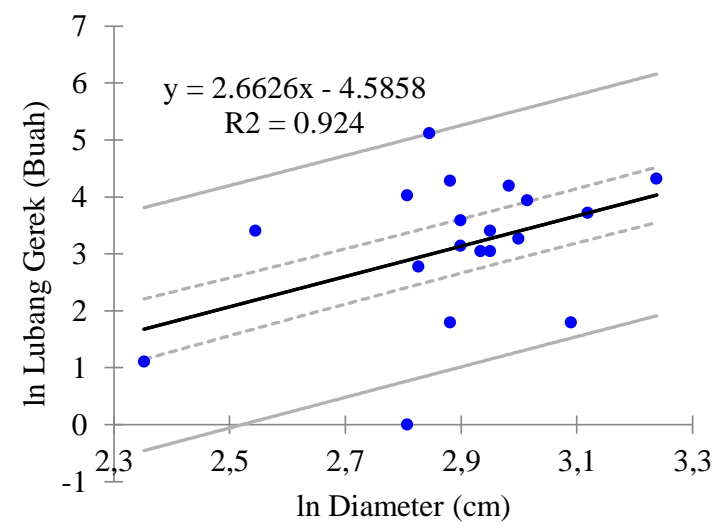

(a)
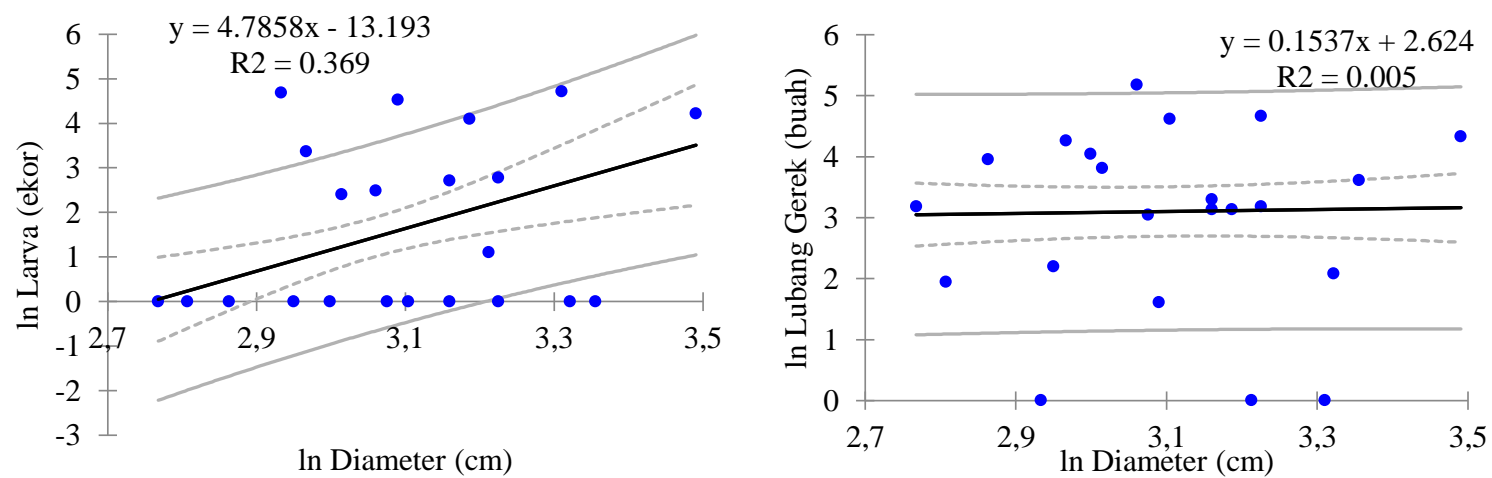

(b) 


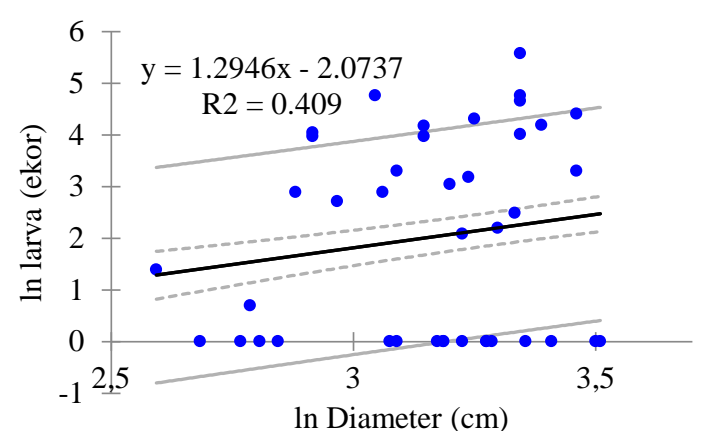

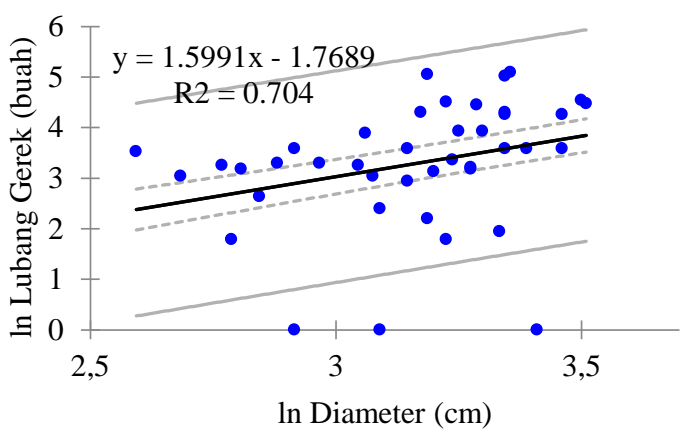

(c)

Gambar 5 Sebaran jumlah larva dan jumlah lubang gerek terhadap diameter berdasarkan umur tanaman: (a) 3 tahun; (b) 4 tahun; (c) 5 tahun.

Untuk jumlah larva dan diameter, pola hubungan yang ada pada tegakan sengon umur 3 tahun berbeda dibandingkan dengan yang ada di umur 4 dan 5 tahun. Pada umur tegakan 3 tahun, peningkatan diameter cenderung mengurangi jumlah larva; sedangkan pada umur tegakan 4 dan 5 tahun memperlihatkan kecenderungan yang bertolak belakang.

Untuk jumlah lubang gerek dan diameter, pola hubungan yang ada pada tegakan sengon 3 tahun sama dengan pola yang ada pada tegakan yang berumur 5 tahun, dimana peningkatan diameter batang pohon cenderung meningkatkan jumlah lubang gerek, sebaliknya pada tegakan 4 tahun tidak memperlihatkan hubungan yang berarti. Pola hubungan pada tegakan yang berumur 4 tahun dengan model linier sederhana: ln lubang gerek $=0.1537$ (ln diameter $)+2.624$ memiliki nilai koefisisen determinasi $\left(\mathrm{R}^{2}\right)$ yang sangat kecil $(5 \%)$ yang artinya hanya $5 \%$ keragaman lubang gerek yang dapat dijelaskan oleh persamaan linier tersebut.

\section{Sebaran Populasi Boktor terhadap Tinggi Pohon Sengon}

Serangan boktor mulai ditemukan pada tinggi total pohon 4 hingga $27 \mathrm{~m}$ (Gambar 6). Boktor paling banyak menyerang pohon pada kisaran tinggi total 18.5-21.5 m (frekuensi $=40$ pohon per ha). Berdasarkan hasil analisis, ditemukan bahwa pada umur 3 tahun, serangan paling parah terjadi pada ketinggian $11.5 \mathrm{~m}$, sedangkan pada umur tegakan 4 tahun terjadi pada ketinggian 19 m. Pada tegakan umur 5 tahun, serangan paling parah terjadi pada kisaran tinggi total $19.0-24.5 \mathrm{~m}$.

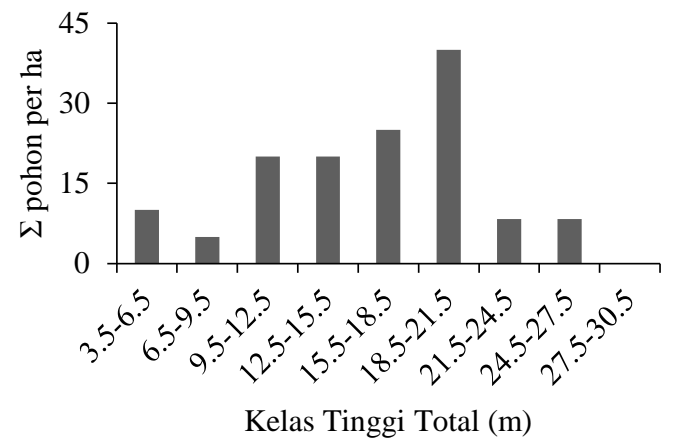

Gambar 6 Sebaran pohon sengon yang terserang berdasarkan kelas tinggi total.

Gambar 7 menyajikan grafik hubungan antara jumlah larva dan jumlah lubang gerek dengan tinggi total pohon yang terserang dengan model linier sederhana. Baik jumlah larva dengan tinggi total maupun jumlah lubang gerek dengan tinggi total pada setiap umur tegakan (3, 4 dan 5 tahun) memperlihatkan pola yang berbeda.
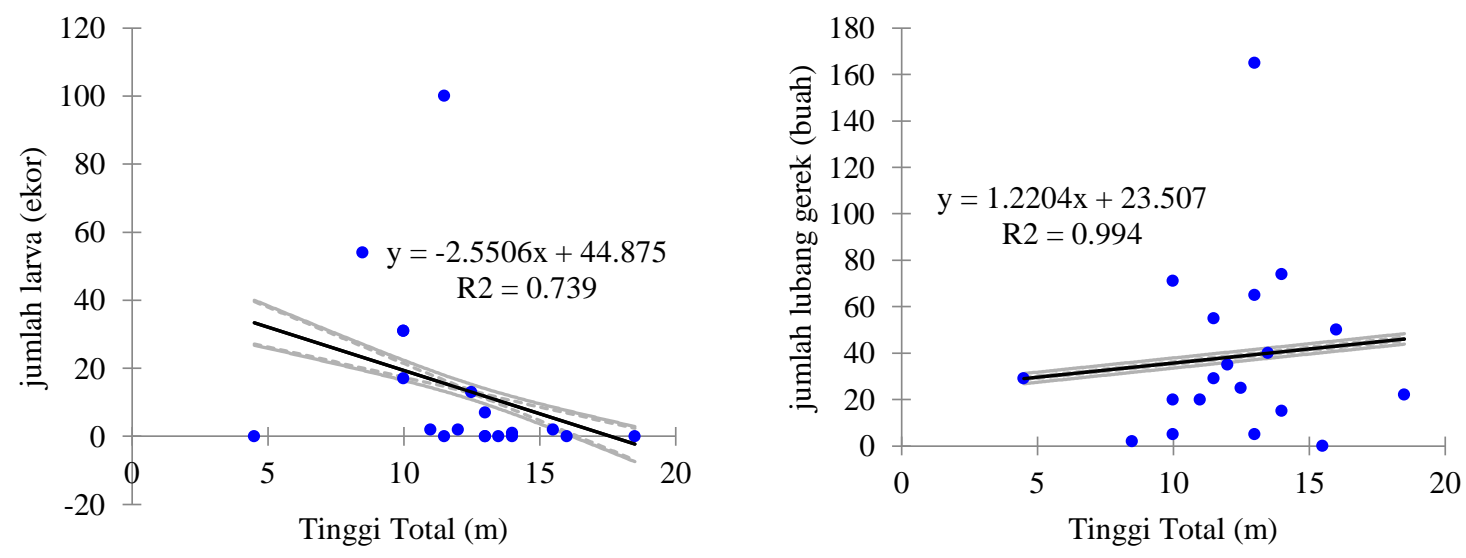

(a) 

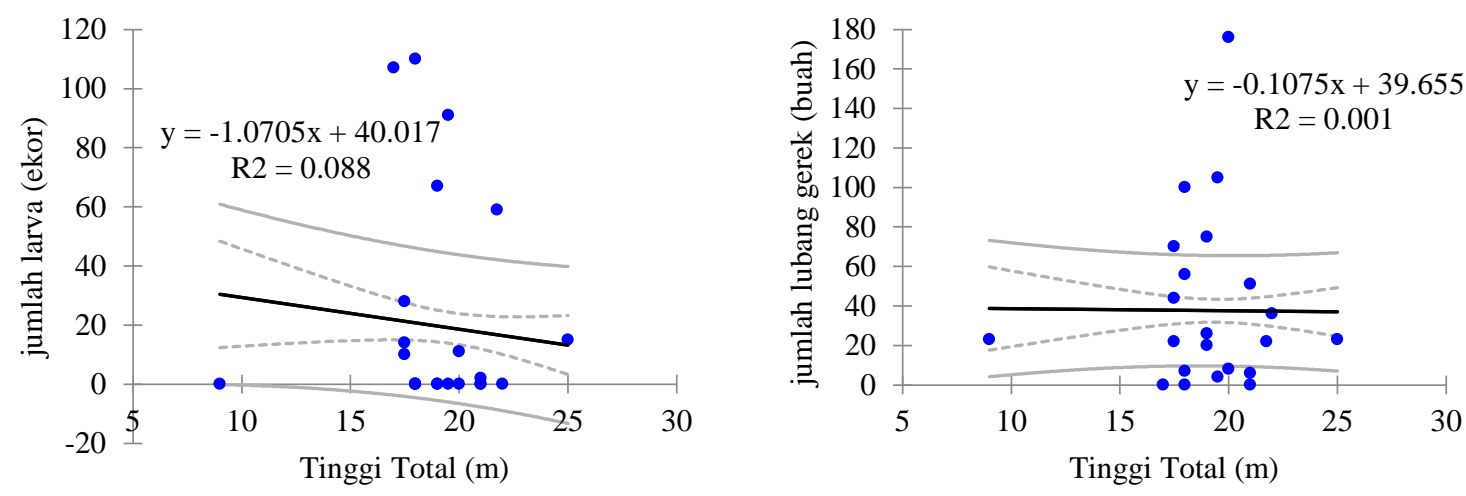

(b)
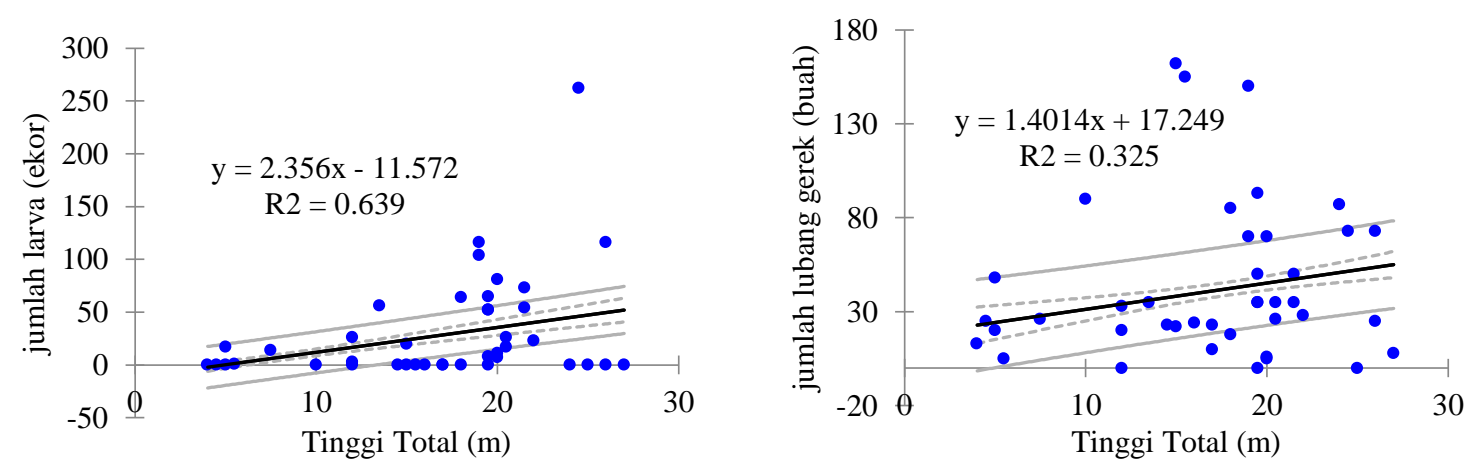

(c)

Gambar 7 Sebaran jumlah larva dan jumlah lubang gerek terhadap tinggi total pohon berdasarkan umur tanaman: (a) 3 tahun; (b) 4 tahun; (c) 5 tahun.

Untuk jumlah larva dan tinggi total, pola hubungan yang ada pada tegakan sengon umur 3 dan 4 tahun berbeda dibandingkan dengan yang ada di umur 5 tahun. Pada umur tegakan 3 dan 4 tahun, peningkatan tinggi total cenderung mengurangi jumlah larva; sedangkan pada umur tegakan 5 tahun memperlihatkan kecenderungan yang sebaliknya.

Untuk jumlah lubang gerek dan tinggi total, pola hubungan yang ada pada tegakan sengon 3 tahun sama dengan pola yang ada pada tegakan yang berumur 5 tahun, dimana peningkatan tinggi total pohon cenderung meningkatkan jumlah lubang gerek, sebaliknya pada tegakan 4 tahun tidak memperlihatkan hubungan yang berarti. Pola hubungan pada tegakan yang berumur 4 tahun dengan model linier sederhana: lubang gerek = 0.1075 (tinggi total) +39.655 memiliki nilai koefisisen determinasi $\left(\mathrm{R}^{2}\right)$ yang kecil $(1 \%)$ yang artinya hanya $1 \%$ keragaman lubang gerek yang dapat dijelaskan oleh persamaan linier tersebut.

\section{Pengaruh Serangan Boktor}

Sebagaimana yang telah dijelaskan, serangan boktor mulai terjadi pada umur tegakan 3 tahun, yaitu saat diameter rata-rata mencapai $16.31 \mathrm{~cm}$ dan tinggi total rata-rata $12.21 \mathrm{~m}$. Letak serangan boktor sangat bervariasi mulai 0 hingga $8.3 \mathrm{~m}$. Serangan boktor akan menimbulkan kerusakan pada bagian dalam kulit hingga bagian gubal kayunya. Akibatnya proses penyerapan air dan unsur hara dari tanah serta fisiologi pohon akan terganggu. Hal tersebut ditandai dengan mengeringnya kulit dan bagian batang yang terkena serangan (Gambar 8a).

Apabila serangan terjadi berulang-ulang dan/atau jumlah larva boktor yang menyerang sangat banyak, maka pohon akan mati. Selain itu, serangan boktor juga dapat menyebabkan patahnya batang pada bagian yang terserang (kering). Patah tersebut dengan mudah terjadi apabila diterpa angin. Kerusakan yang terjadi pada batang sengon berupa lubang gerek dan saluran gerek. Akibatnya volume dan kualitas kayu yang dihasilkan akan menurun. 


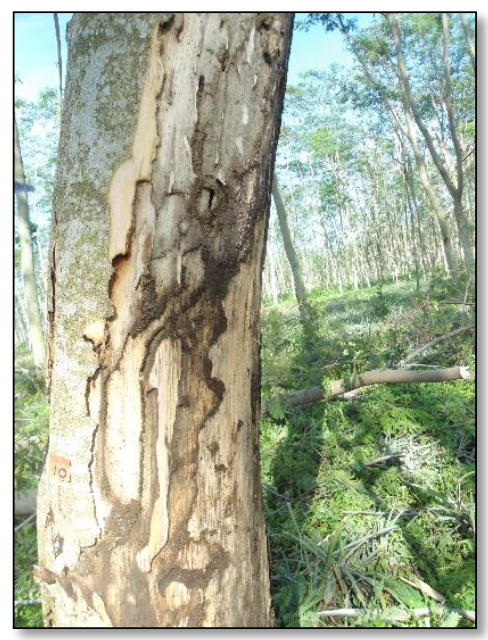

(a)

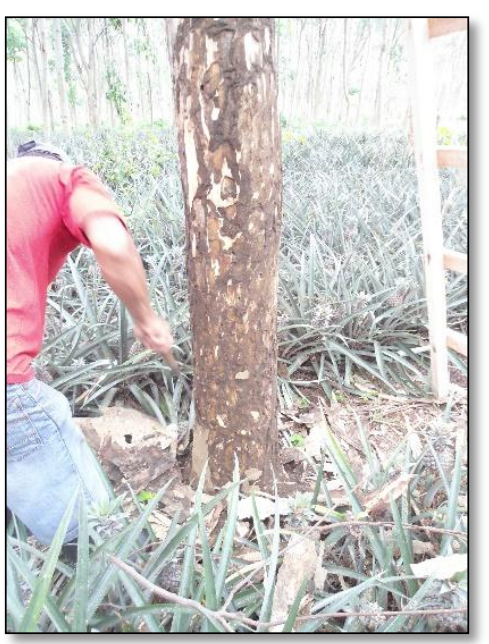

(b)

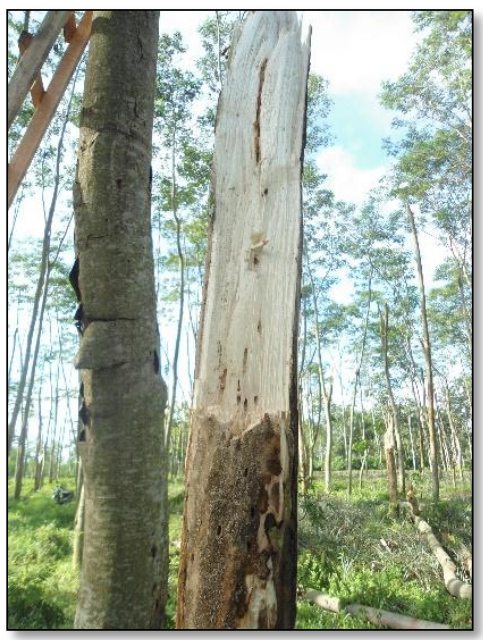

(c)

Gambar 8 Bentuk kerusakan serangan boktor pada pohon sengon: (a) Kulit dan batang sengon mengering; (b) Lokasi serangan boktor mulai $0 \mathrm{~m}$ (permukaan tanah); (c) Pohon sengon yang patah akibat rapuh batang setelah serangan boktor.

\section{KESIMPULAN}

Serangan boktor ditemukan pada umur tegakan 3 tahun dan mengalami peningkatan baik persentase serangan maupun tingkat kerusakan seiring dengan bertambahnya umur tegakan. Hal tersebut dikarenakan pertambahan diameter dan tinggi pohon menyebabkan semakin banyaknya sumber makanan boktor dan terdapatnya ruang hidup yang luas bagi perkembangan boktor. Persentase serangan dan tingkat kerusakan tertinggi terjadi pada tegakan sengon umur 5 tahun (53.71\% dan $38.07 \%$ ). Peningkatan serangan boktor disebabkan oleh melimpahnya sumber makanan, perilaku serangga dan faktor perlakuan pengendalian. Boktor paling banyak menyerang pada kisaran diameter $15.5-18.5 \mathrm{~cm}$ (frekuensi $=30$ pohon per ha), dan pada tinggi total pohon $18.5-21.5 \mathrm{~m}$ (frekuensi $=40$ pohon per ha).

\section{UCAPAN TERIMA KASIH}

Terima kasih dan penghargaan kami sampaikan kepada Direktorat Jenderal Pendidikan Tinggi yang telah memberikan Beasiswa Unggulan Dikti kepada peneliti tahun anggaran 2012-2014 dan KPH Kediri, Perum Perhutani Unit II Jawa Timur atas fasilitas dan bantuan yang diberikan.

\section{DAFTAR PUSTAKA}

Flowrensia L, Siregar UJ, Haneda NF, Faidah AN. 2015. Distribution of boktor Xystricera festiva, major pest of Falcataria sp. In eight population.
Di dalam: Surasih M, Hadi I, Faturrahman, Ihsan M., editor. International Seminar on Tropical natural Resources 2015; 2015 Jun 1013; Mataram, Indonesia. Mataram (ID): Mataram University Press. hlm 191-198.

Herdiana N. 2010. Potensi serangan hama tanaman jati rakyat dan upaya pengendaliannya di Rumpin, Bogor. Jurnal Penelitian hutan Tanaman [internet]. [diunduh 2015 Mar 23]; 7(4): 177185. Tersedia pada: http://fordamof.org/files/7.4.2010_potensi_serangan.pdf.

Husaeni EA. 2010. Xystrocera festiva Thoms (Cerambycidae: Coleoptera): Biologi dan Pengendaliannya pada Hutan Tanaman Sengon. Bogor (ID): IPB Pr.

Ichtisinii A. 2011. Identifikasi komponen kimia kulit dan kayu pohon snegon yang dimakan larva Xystrocera festiva Thoms (Cerambycidae. Coleoptera) [Skripsi]. Bogor (ID): Institut Pertanian Bogor.

Matsumoto K. 1994. Studies on the ecological characteristics and method of control of insect pest of trees in reforested areas in Indonesia. AFRD, Bogor.

SNI [Standar Nasional Indonesia]. 2001. Kayu bundar sengon dan jabon. [internet]. [diunduh 2016 Mar 5]. Tersedia pada: http://www.dephut.go.id/Halaman/STANDARD ISASI_\%26_LINGKUNGAN_KEHUTANAN/ SNI/KB_Sengon.htm.

Tarumingkeng RC. 1994. Dinamika Populasi: Kajian ekologi kuantitatif. Jakarta (ID): Pustaka Sinar Harapan Anggota Ikapi. 
Lampiran

Tabel 4 Kondisi umum dan lingkungan lokasi penelitian

\begin{tabular}{|c|c|c|c|c|c|c|c|c|}
\hline $\begin{array}{l}\text { Plot } \\
\text { Contoh }\end{array}$ & $\begin{array}{c}\text { Umur } \\
\text { Tanaman } \\
\text { (tahun) }\end{array}$ & Petak & $\begin{array}{l}\text { Tahun } \\
\text { Tanam }\end{array}$ & Titik Koordinat & Elevasi & Suhu & $\mathrm{KR}$ & $\begin{array}{l}\text { Jumlah } \\
\text { Pohon } \\
\text { per ha }\end{array}$ \\
\hline 1 & 1 & $108 \mathrm{~F}$ & 2014 & $\begin{array}{l}\text { S } 007^{\circ} 56^{\prime} 19.1^{\prime \prime} \\
\text { E } 112^{\circ} 12^{\prime} 19.0^{\prime \prime}\end{array}$ & $471 \mathrm{mdpl}$ & $33^{\circ} \mathrm{C}$ & $67 \%$ & 410 \\
\hline 2 & 1 & $108 \mathrm{~F}$ & 2014 & $\begin{array}{l}\text { S } 007^{\circ} 56^{\prime} 15.4^{\prime \prime} \\
\text { E } 112^{\circ} 12^{\prime} 17.5^{\prime \prime}\end{array}$ & 457 mdpl & $35^{\circ} \mathrm{C}$ & $61 \%$ & 570 \\
\hline 3 & 2 & $130 \mathrm{~A}$ & 2013 & $\begin{array}{l}\text { S } 007^{\circ} 55^{\prime} 51.5^{\prime \prime} \\
\text { E } 112^{\circ} 11^{\prime} 45.6^{\prime \prime}\end{array}$ & 417 mdpl & $31^{\circ} \mathrm{C}$ & $78 \%$ & 760 \\
\hline 4 & 2 & $130 \mathrm{~A}$ & 2013 & $\begin{array}{l}\text { S } 007^{\circ} 55^{\prime} 46.7^{\prime \prime} \\
\text { E } 112^{\circ} 11^{\prime} 42.3^{\prime \prime}\end{array}$ & 424 mdpl & $29^{\circ} \mathrm{C}$ & $81 \%$ & 680 \\
\hline 5 & 3 & $100 \mathrm{~B}$ & 2012 & $\begin{array}{l}\text { S } 007^{\circ} 54^{\prime} 58.8^{\prime \prime} \\
\text { E } 112^{\circ} 11^{\prime} 30.6^{\prime \prime}\end{array}$ & 389 mdpl & $27^{\circ} \mathrm{C}$ & $85 \%$ & 390 \\
\hline 6 & 3 & $100 \mathrm{~B}$ & 2012 & $\begin{array}{l}\text { S } 007^{\circ} 55^{\prime} 05.1^{\prime \prime} \\
\text { E } 112^{\circ} 11^{\prime} 30.7^{\prime \prime}\end{array}$ & 407 mdpl & $26^{\circ} \mathrm{C}$ & $89 \%$ & 550 \\
\hline 7 & 4 & 122 & 2011 & $\begin{array}{l}\text { S } 007^{\circ} 57^{\prime} 09.2^{\prime \prime} \\
\text { E } 112^{\circ} 11^{\prime} 42.7^{\prime \prime}\end{array}$ & $426 \mathrm{mdpl}$ & $29^{\circ} \mathrm{C}$ & $74 \%$ & 490 \\
\hline 8 & 4 & 125 & 2011 & $\begin{array}{l}\text { S } 007^{\circ} 56^{\prime} 53.6^{\prime \prime} \\
\text { E } 112^{\circ} 12^{\prime} 03.8^{\prime \prime}\end{array}$ & 447 mdpl & $31^{\circ} \mathrm{C}$ & $72 \%$ & 360 \\
\hline 9 & 5 & 121 & 2010 & $\begin{array}{l}\text { S } 007^{\circ} 57^{\prime} 25.4^{\prime \prime} \\
\text { E } 112^{\circ} 11^{\prime} 51.4^{\prime \prime}\end{array}$ & 446 mdpl & $29^{\circ} \mathrm{C}$ & $79 \%$ & 450 \\
\hline 10 & 5 & 121 & 2010 & $\begin{array}{l}\text { S } 007^{\circ} 57^{\prime} 19.8^{\prime \prime} \\
\text { E } 112^{\circ} 11^{\prime} 54.7^{\prime \prime}\end{array}$ & 440 mdpl & $27^{\circ} \mathrm{C}$ & $85 \%$ & 270 \\
\hline
\end{tabular}

Ket: KR = Kelembaban relatif 